\title{
The fibrinolytic enzyme system in hepatic cirrhosis and malignant metastases
}

\author{
D. OGSTON, N. B. BENNETT, AND C. M. OGSTON \\ From the Department of Medicine, University of Aberdeen
}

SYNOPSIS Components of the blood fibrinolytic system were measured in 18 patients with hepatic cirrhosis, in two patients with acute hepatic necrosis, and in 10 patients with hepatic metastases. The frequency of an elevation of plasminogen activator and a reduction in plasminogen in hepatic cirrhosis has been confirmed. Patients with compensated cirrhosis had low levels of the serum inhibitor of plasminogen activation while those with severe hepatic insufficiency or coma due to cirrhosis or hepatic necrosis had elevated levels. The presence of hepatic metastases was associated with reduced plasminogen activator levels and an increase in the fibrinogen concentration.

Human blood contains an enzyme system which, on activation, results in the formation of plasmin, an endopeptidase activity at near neutrality. An integral component of this system (the fibrinolytic enzyme system) is plasminogen, a $\beta$-globulin, which is converted to plasmin under the influence of activators. The number and source of plasminogen activators is uncertain, but there is substantial evidence that vascular endothelial cells are at least one source (Todd, 1958). Inhibitors probably have an important regulating role in the fibrinolytic system. Antiplasmins, principally $a_{2}$-macroglobulin and $a_{1}$-antitrypsin, are present in considerable quantities in blood, and recently it has been shown that the coagulation of blood is associated with the appearance of an inhibitor of plasminogen activation (Bennett, 1967; Helle, 1968; Bennett, 1970).

Abnormal blood fibrinolytic activity in patients with hepatic cirrhosis has been recognized since the earlier years of this century when Goodpasture (1914) reported that the clots formed from blood obtained from patients with cirrhosis underwent lysis more rapidly than did clots from the blood of control subjects. This finding has been confirmed repeatedly (Ratnoff, 1949; Kwaan, McFadzean, and Cook, 1956; Bergström, Blombäck, and Kleen, 1960; Grossi, Moreno, and Rousselot, 1961). Ratnoff (1949) observed that rapid lysis of plasma clots occurred also in patients with hepatic damage other than cirrhosis, but not in obstructive jaundice or acute hepatitis. The mechanism of the increased Received for publication 15 April 1971. blood fibrinolytic activity in portal cirrhosis has not been established; impaired hepatic clearance of plasminogen activator or a decrease in the level of inhibitors of fibrinolysis are the principal alternative hypotheses.

We report our findings on the measurements of the major known components of the fibrinolytic enzyme system in the blood of patients with hepatic cirrhosis, acute necrosis, and malignant metastases.

\section{Methods and Patients}

PLASMINOGEN ACTIVATOR

Plasminogen activator was assessed by performing euglobulin clot lysis times by the method of Nilsson and Olow (1962). The results were expressed by plotting the lysis times logarithmically against units of fibrinolytic activity (Sherry, Lindemeyer, Fletcher, and Alkjaersig, 1959), 10 units being arbitrarily equated with a lysis time of 50 minutes.

\section{PLASMINOGEN}

This was measured by the caseinolytic technique of Alkjaersig, Fletcher, and Sherry (1959a) and the results expressed in Sherry units (Alkjaersig, Fletcher, and Sherry, 1959b).

SERUM INHIBITOR

Serum inhibitor of plasminogen activation was measured using a standard clot system as described by Bennett (1967). One unit of inhibition is equiv- 
alent to that produced by $10^{-3} \mathrm{M}$ epsilon aminocaproic acid.

\section{PLASMA ANTIPLASMIN ACTIVITY}

This was measured by the technique of Sherry et al (1959) using plasmin prepared by spontaneous activation of plasminogen in $50 \%$ glycerol. The results are expressed as the percentage inhibition of the standard plasmin preparation. The plasminogen used to prepare the plasmin was obtained from AB Kabi, Stockholm.

\section{FIBRINOGEN}

Fibrinogen was measured by a modification (Ogston and Ogston, 1966) of the method of Ratnoff and Menzie (1951).

\section{PATIENTS}

Thirty patients with liver disease were studied. Their diagnosis was established by history, examination, and laboratory findings aided, in some patients, by the histological appearances of tissue obtained at biopsy or necropsy. The diagnosis was confirmed subsequently at operation or necropsy in a number of patients.

Blood samples were obtained before the start of specific drug therapy or surgery, and before blood replacement.

\section{NORMAL VALUES}

Control plasminogen activator levels were obtained from healthy subjects or patients convalescent from a variety of minor disorders. All had been at rest in bed for at least 12 hours.
The control values for plasminogen, fibrinogen, serum inhibitor of plasminogen activation, and plasma antiplasmin activity were obtained from healthy volunteers aged between 35 and 75 . All were free from symptoms of physical disease and had a Westergren erythrocyte sedimentation rate in the normal range (Hilder and Gunz, 1964).

\section{Results}

NORMAL VALUES

Control levels, means, and standard deviations for plasminogen activator, plasminogen, fibrinogen, activation inhibitor, and antiplasmin activity are shown in Table $\mathbf{I}$.

\begin{tabular}{lccc}
\hline & $\begin{array}{l}\text { No. of } \\
\text { Subjects }\end{array}$ & Mean & $S D$ \\
\hline Activator (units) & 25 & $4 \cdot 8$ & $1 \cdot 5$ \\
Plasminogen (casein units/ml) & 110 & 4.4 & 0.5 \\
Fibrinogen (mg/100 ml) & 110 & 356 & 60 \\
Activation inhibitor (units) & 52 & 2.45 & 0.5 \\
Antiplasmin (\% inhibition) & 44 & $45 \cdot 2$ & 6.5 \\
\hline
\end{tabular}

Table I Values for plasminogen activator, plasminogen, fibrinogen, activation inhibitor, and antiplasmin in normal subjects

PORTAL CIRRHOSIS

The biochemical and clinical findings of the patients with portal cirrhosis, together with the levels of the components of the blood fibrinolytic enzyme system

\begin{tabular}{|c|c|c|c|c|c|c|}
\hline \multirow[t]{2}{*}{ Subject } & \multirow[t]{2}{*}{$\operatorname{Sex}$} & \multirow[t]{2}{*}{ Age } & \multirow[t]{2}{*}{ Diagnosis } & \multicolumn{3}{|l|}{ Clinical State } \\
\hline & & & & Coma or Precoma & Ascites & Varices \\
\hline $\begin{array}{r}1 \\
2 \\
3 \\
4 \\
5 \\
6 \\
7 \\
8 \\
9 \\
10 \\
11 \\
12 \\
13 \\
14 \\
15 \\
16 \\
17 \\
18 \\
19 \\
20\end{array}$ & $\begin{array}{l}\mathbf{F} \\
\mathbf{M} \\
\mathbf{M} \\
\mathbf{F} \\
\mathbf{M} \\
\mathbf{F} \\
\mathbf{F} \\
\mathbf{M} \\
\mathbf{M} \\
\mathbf{F} \\
\mathbf{F} \\
\mathbf{F} \\
\mathbf{M} \\
\mathbf{M} \\
\mathbf{M} \\
\mathbf{M} \\
\mathbf{F} \\
\mathbf{F} \\
\mathbf{F} \\
\mathbf{F}\end{array}$ & $\begin{array}{l}34 \\
43 \\
57 \\
67 \\
68 \\
57 \\
68 \\
53 \\
36 \\
53 \\
78 \\
59 \\
65 \\
62 \\
66 \\
58 \\
66 \\
65 \\
26 \\
49\end{array}$ & $\begin{array}{l}\text { Crytogenic portal cirrhosis } \\
\text { Posthepatitic cirrhosis } \\
\text { Alocholic portal cirrhosis }^{1} \\
\text { Cryptogenic portal cirrhosis } \\
\text { Hepatic cirrhosis, pneumonia } \\
\text { Cryptogenic portal cirrhosis } \\
\text { Cryptogenic portal cirrhosis } \\
\text { Alcoholic portal cirrhosis } \\
\text { Cryptogenic portal cirrhosis } \\
\text { Alcoholic portal cirrhosis } \\
\text { Posthepatic cirrhosis } \\
\text { Cryptogenic portal cirrhosis } \\
\text { Alcoholic portal cirrhosis } \\
\text { Cryptogenic portal cirrhosis } \\
\text { Haemochromatosis, hepatic cirrhosis }{ }^{1} \\
\text { Haemochromatosis, hepatic cirrhosis } \\
\text { Cryptogenic portal cirrhosis } \\
\text { Alcoholic portal cirrhosis } \\
\text { Infective hepatitis, hepatic necrosis }{ }^{1} \\
\text { Infective hepatitis, hepatic necrosis }\end{array}$ & $\begin{array}{l}0 \\
+ \\
0 \\
+ \\
+ \\
0 \\
0 \\
0 \\
0 \\
0 \\
0 \\
0 \\
0 \\
0 \\
+ \\
0 \\
0 \\
+ \\
+ \\
+\end{array}$ & $\begin{array}{l}+ \\
+ \\
+ \\
0 \\
0 \\
+ \\
0 \\
0 \\
+ \\
+ \\
+ \\
+ \\
+ \\
+ \\
+ \\
0 \\
0 \\
+ \\
0 \\
+\end{array}$ & $\begin{array}{l}+ \\
+ \\
+ \\
0 \\
+ \\
+ \\
+ \\
+ \\
+ \\
+ \\
+ \\
+ \\
+ \\
+ \\
0 \\
0 \\
0 \\
0 \\
0 \\
+\end{array}$ \\
\hline
\end{tabular}

Table II Details of patients with portal cirrhosis and acute hepatic necrosis 
measured, are presented in Table II. The fibrinolytic components showed a number of striking alterations. The plasminogen activator level was measured in i 4 patients and was elevated (over 8 units) in eight. Twelve of the 18 patients had a plasminogen level more than 2 SD below the mean for control subjects, and in six patients the level was less than 2.0 casein units $/ \mathrm{ml}$. A single patient (no. 3) was treated with epsilon-aminocaproic acid; his plasminogen level rose from 0.9 to 2.3 casein units/ml over the five days of this therapy. However, the relationship between the plasminogen activator and plasminogen level did not reach statistical significance $(r=-0.33$; $P>0 \cdot 1)$. The majority of patients had fibrinogen levels which were not markedly abnormal, but, taking age into account, a number had reduced levels. Antiplasmin levels were variable with a trend towards reduced levels, but only four of the patients had levels more than twice the standard deviation below the mean for normal subjects. The level of the serum inhibitor of plasminogen activator varied widely. A small number had increased levels; this appeared to be related to the presence of clinical manifestations of hepatic insufficiency and coma. Some patients with portal cirrhosis had abnormally low levels of the serum inhibitor of plasminogen activation: the reduced levels did not correlate with other parameters measured and, notably, not with the antiplasmin activity.

HEPATIC NECROSIS

The two patients who died with acute hepatic necrosis following viral hepatitis had a markedly reduced plasminogen level (Table $\mathrm{II}$ ). In the patient in whom it was assayed the serum inhibitor of plasminogen activation was greatly increased as in the patients with cirrhosis and severe hepatic failure.

\section{HEPATIC METASTASES}

The majority of the 10 patients with liver metastases had reduced plasminogen activator levels (Table III): most had a moderate increase in the plasma fibrinogen concentration. The plasminogen level was within the normal range in five patients and reduced in five, but only a single patient had a very low level. The inhibitor assays were within the normal range apart from two patients with an elevated level of the inhibitor of plasminogen activation.

\section{Discussion}

There is general agreement that plasma fibrinolytic activity is increased in patients with portal cirrhosis. The mechanism, however, remains in debate. A high level of plasminogen activator in cirrhotic tissue was shown by Astrup, Rasmussen, Amery, and Poulsen (1960) and its relation to increased plasma levels postulated. There are experimental data that the normal liver clears plasminogen activator from the plasma (Grossi, Rousselot, and Panke, 1962; Fletcher, Biederman, Moore, Alkjzersig, and Sherry, 1964). Fletcher and his associates (1964) provided evidence that the hepatic clearance of activator may be deficient in the cirrhotic patient; this was considered responsible for the greatly enhanced plasminogen activator activity found in patients with hepatic cirrhosis exposed to such stimuli as electroshock therapy or intravenous

\begin{tabular}{|c|c|c|c|c|c|c|c|c|}
\hline $\begin{array}{l}\text { Albumin } \\
(\mathrm{g} / 100 \mathrm{ml})\end{array}$ & $\begin{array}{l}\text { Bilirubin } \\
(\mathrm{mg} / 100 \mathrm{ml})\end{array}$ & $\begin{array}{l}\text { Alkaline } \\
\text { Phosphatase } \\
\text { (units) }\end{array}$ & SGOT (units) & $\begin{array}{l}\text { Plasminogen } \\
\text { Activator } \\
\text { (units) }\end{array}$ & $\begin{array}{l}\text { Fibrinogen } \\
(\mathrm{mg} / \mathrm{l} 00 \mathrm{ml})\end{array}$ & $\begin{array}{l}\text { Plasminogen } \\
\text { (casein } \\
\text { units } / m l)\end{array}$ & $\begin{array}{l}\text { Antiplasmin } \\
\text { Activity }(\% \\
\text { inhibition) }\end{array}$ & $\begin{array}{l}\text { Activation } \\
\text { Inhibitor } \\
\text { (units) }\end{array}$ \\
\hline $2 \cdot 7$ & $0 \cdot 2$ & 34 & 53 & $13 \cdot 2$ & 255 & $2 \cdot 7$ & $40 \cdot 6$ & $2 \cdot 30$ \\
\hline- & $4 \cdot 0$ & 13 & 28 & - & 165 & $1 \cdot 0$ & $36 \cdot 0$ & $>10$ \\
\hline $3 \cdot 2$ & $1 \cdot 0$ & 13 & 46 & $8 \cdot 8$ & 260 & 0.9 & $48 \cdot 1$ & 1.90 \\
\hline $2 \cdot \overline{2}$ & 0.9 & 18 & 30 & $8 \cdot 2$ & 305 & $1 \cdot 4$ & - & - \\
\hline $2 \cdot 7$ & $5 \cdot 2$ & 13 & 158 & - & 800 & $2 \cdot 0$ & - & - \\
\hline $2 \cdot 8$ & $1 \cdot 5$ & 30 & 92 & $2 \cdot 7$ & 340 & $2 \cdot 3$ & - & - \\
\hline $3 \cdot 1$ & $5 \cdot 8$ & 9 & 36 & $11 \cdot 0$ & 295 & $3 \cdot 7$ & $43 \cdot 9$ & $1 \cdot 85$ \\
\hline $3 \cdot 4$ & 0.7 & 15 & 71 & - & 255 & $3 \cdot 0$ & $52 \cdot 8$ & $1 \cdot 20$ \\
\hline $2 \cdot 7$ & $3 \cdot 0$ & 17 & 54 & $5 \cdot 8$ & 220 & $2 \cdot 1$ & $31 \cdot 7$ & 3.05 \\
\hline $2 \cdot 7$ & $2 \cdot 1$ & 16 & 66 & $2 \cdot 7$ & 455 & $3 \cdot 9$ & $58 \cdot 0$ & $1 \cdot 80$ \\
\hline $2 \cdot 7$ & $8 \cdot 8$ & 26 & 137 & $14 \cdot 0$ & 158 & 2.0 & $27 \cdot 5$ & $5 \cdot 50$ \\
\hline $3 \cdot 0$ & $2 \cdot 2$ & 58 & 124 & $16 \cdot 5$ & 230 & $1 \cdot 9$ & $35 \cdot 6$ & 0.70 \\
\hline $3 \cdot 1$ & $1 \cdot 1$ & 24 & 56 & $10 \cdot 0$ & 410 & $4 \cdot 0$ & $45 \cdot 4$ & $3 \cdot 70$ \\
\hline 3.0 & 0.7 & 33 & 33 & $6 \cdot 6$ & 270 & $3 \cdot 6$ & $31 \cdot 6$ & $1 \cdot 30$ \\
\hline $2 \cdot 8$ & $1 \cdot 4$ & 8 & 207 & $2 \cdot 1$ & 385 & $3 \cdot 6$ & $51 \cdot 2$ & $>10$ \\
\hline $3 \cdot 2$ & $1 \cdot 1$ & 15 & 30 & $12 \cdot 3$ & 350 & $1 \cdot 5$ & $44 \cdot 6$ & 0.70 \\
\hline $3 \cdot 5$ & $1 \cdot 3$ & 23 & 54 & $5 \cdot 5$ & 275 & $3 \cdot 3$ & $27 \cdot 5$ & 1.85 \\
\hline $4 \cdot 2$ & $18 \cdot 1$ & 9 & 142 & - & 355 & $1 \cdot 1$ & 55.9 & $4 \cdot 70$ \\
\hline $4 \cdot 7$ & 10.5 & 24 & $>860$ & - & 227 & 0.2 & - & - \\
\hline $2 \cdot 2$ & $6 \cdot 1$ & 21 & 129 & 2.9 & 365 & $1 \cdot 1$ & 48.9 & $>10$ \\
\hline
\end{tabular}

Table II Details of patients with portal cirrhosis and acute hepatic necrosis-continued 


\begin{tabular}{|c|c|c|c|c|c|c|c|c|c|c|c|c|}
\hline Subject & $\begin{array}{l}\text { Site of } \\
\text { Primary } \\
\text { Malignancy }\end{array}$ & Sex & $\begin{array}{l}\text { Age } \\
(y r)\end{array}$ & $\begin{array}{l}\text { Albumin } \\
(\mathrm{g} / 100 \mathrm{ml})\end{array}$ & $\begin{array}{l}\text { Bilirubin } \\
(\mathrm{mg} / 100 \mathrm{ml})\end{array}$ & $\begin{array}{l}\text { Alkaline } \\
\text { Phosphatase } \\
\text { (units) }\end{array}$ & $\begin{array}{l}\text { SGOT } \\
\text { (units) }\end{array}$ & $\begin{array}{l}\text { Plasminogen } \\
\text { Activator } \\
\text { (units) }\end{array}$ & $\begin{array}{l}\text { Fibrinogen } \\
(\mathrm{mg} / 100 \mathrm{ml})\end{array}$ & $\begin{array}{l}\text { Plasminogen } \\
\text { (casein } \\
\text { units } / m l)\end{array}$ & $\begin{array}{l}\text { Antiplasmin } \\
\text { Activity } \\
(\% \text { inhibition) }\end{array}$ & $\begin{array}{l}\text { Activation } \\
\text { Inhibitor } \\
\text { (units) }\end{array}$ \\
\hline 1 & Bile duct & $\mathbf{F}$ & 76 & $3 \cdot 1$ & $4 \cdot 1$ & 83 & - & $1 \cdot 4$ & 508 & $2 \cdot 4$ & $52 \cdot 3$ & - \\
\hline 2 & Stomach & $\mathbf{M}$ & 53 & $3 \cdot 2$ & $3 \cdot 3$ & 82 & 205 & $<1.0$ & 425 & $3 \cdot 0$ & $57 \cdot 0$ & - \\
\hline 3 & Oesophagus & $\mathbf{M}$ & 45 & $3 \cdot 2$ & $23 \cdot 0$ & 85 & 220 & - & 574 & $2 \cdot 5$ & - & - \\
\hline 4 & Oesophagus & $\mathbf{F}$ & 83 & $3 \cdot 6$ & $1 \cdot 6$ & 69 & 147 & 1.9 & 517 & $2 \cdot 7$ & - & 一 \\
\hline 5 & Not known & $\mathbf{F}$ & 61 & $3 \cdot 0$ & $1 \cdot 1$ & 22 & 21 & $4 \cdot 3$ & 405 & $3 \cdot 4$ & - & - \\
\hline 6 & Stomach & $\mathbf{F}$ & 55 & $2 \cdot 2$ & $12 \cdot 3$ & 140 & - & $<1.0$ & 335 & 1.0 & $58 \cdot 1$ & $>10$ \\
\hline 7 & Ovary & $\mathbf{F}$ & 83 & $3 \cdot 0$ & $12 \cdot 0$ & 96 & 57 & $1 \cdot 7$ & 420 & $3 \cdot 7$ & $42 \cdot 7$ & $2 \cdot 30$ \\
\hline 8 & Not known & $\mathbf{F}$ & 74 & - & $12 \cdot 7$ & 70 & 60 & $2 \cdot 6$ & 475 & $3 \cdot 8$ & $44 \cdot 5$ & $2 \cdot 65$ \\
\hline 9 & Melanoma & $\mathbf{F}$ & 73 & $2 \cdot 4$ & 0.4 & 16 & 20 & $5 \cdot 8$ & 560 & $4 \cdot 1$ & $47 \cdot 0$ & 1.65 \\
\hline 10 & Thyroid & $\mathbf{F}$ & 77 & $2 \cdot 4$ & 0.5 & 14 & 14 & $<1.0$ & 410 & $3 \cdot 8$ & $66 \cdot 2$ & $7 \cdot 20$ \\
\hline
\end{tabular}

Table III Details of patients with hepatic metastases

nicotinic acid, and the increased plasminogen activator level was considered responsible for the resultant fall in plasma plasminogen levels. However, a number of investigators have found that patients with cirrhosis have a decreased level of blood antiplasmin activity (Purcell and Phillips, 1963; O'Connell, Grossi, and Rousselot, 1964; Tytgat, Collen, de Vreker, and Verstraete, 1968) and have related this finding to the increased fibrinolysis in hepatic cirrhosis. In this context it is relevant that Mattii, Ambrus, Sokal, and Mink (1964) found that isolated rat liver produced antiplasmin, but not plasminogen activators or plasminogen.

Our results again point to the frequency of increased levels of circulating plasminogen activator in patients with hepatic cirrhosis and, in keeping with most other investigators (Purcell and Phillips, 1963; Fletcher et al, 1964), confirm that the plasma plasminogen level is often reduced. In contrast, Das and Cash (1969) did not find a reduced mean plasminogen level in their patients; those patients had probably less advanced and severe cirrhosis. The reduction in the plasminogen concentration may be due to its consumption secondary to the systematic increase in activator level consequent on its impaired hepatic clearance (Fletcher et al, 1964); this view is supported by our finding that the use of the fibrinolytic inhibitor, epsilon-aminocaproic acid, was followed by an increase in the plasminogen level. Alternatively the low plasminogen levels may be the result of disseminated intravascular coagulation which can occur in cirrhosis (Bergström et al, 1960; Zetterqvist and von Franken, 1963; Johansson, 1964; Blombäck, Carlson, Franzen, and Zetterqvist, 1966) and which has been shown to be a prominent mechanism in acute hepatic necrosis (Rake, Flute, Pannell, and Williams, 1970). A further possibility is that the lowered plasminogen levels could result from impaired hepatic synthesis, but evidence points to eosinophil granulocytes rather than the liver as the site of plasminogen synthesis in man (Barnhart and Riddle, 1963).
We have found that some patients with portal cirrhosis have decreased antiplasmin levels. The findings in respect of the other inhibitors measured, the serum inhibitor of plasminogen activation, are of interest; this inhibitor is distinct from antiplasmins and plasma antiurokinase activity and levels in hepatic disease have not been reported. They appear to be reduced in compensated cirrhosis, but elevated in hepatic failure. A possible explanation is that the plasma precursor of this inhibitor is released from injured cells: a rise has also been observed following myocardial infarction and surgical trauma (Bennett, Ogston, and Ogston, 1967). The significance of the alterations in the serum inhibitor of plasminogen activation in relation to the clinical features of cirrhosis is obscure in the absence of an understanding of the role of this and other inhibitors in the control of fibrinolytic activity in vivo.

Decreased fibrinolysis has been reported in primary carcinoma of the liver associated with the appearance in the blood of an antiactivator, but not antiplasmin activity (Kwaan, Lo, and McFadzean, 1959). Fletcher and his associates (1964) noted that patients with metastatic carcinomatous involvement of the liver did not exhibit enhanced plasminogen activator levels after the administration of nicotinic acid. A number of patients in the present study with hepatic metastases had reduced plasminogen levels in association with low activator levels. The explanation is not apparent, but the reduced plasminogen levels may be secondary to disseminated intravascular coagulation which may occur in disseminated cancer (Merskey, Johnson, Kleiner, and Wohl, 1967).

We are grateful to Mrs Helen Lee for technical help.

\section{References}

Alkjaersig, N., Fletcher, A. P., and Sherry, S. (1959a). The mechanism of clot dissolution by plasmin. J. clin. Invest., 38, 1086-1095.

Alkjaersig, N., Fletcher, A. P., and Sherry, S. (1959b). €-aminocaproic acid: an inhibitor of plasminogen activation. J. biol. Chem., 234, 832-837. 
Astrup, T., Rasmussen, T., Amery, A., and Poulsen, H. E. (1960). Fibrinolytic activity of cirrhotic liver. Nature (Lond.), 185, 619-620.

Barnhart, M., and Riddle, J. (1963). Cellular localization of profibrinolysin (plasminogen). Blood, 21, 306-321.

Bennett, N. B. (1967). A method for the quantitative assay of inhibitor of plasminogen activation in human serum. Thrombos. Diathes, haemorrh. (Stuttg.), 17, 12-22.

Bennett, N. B. (1970). Further studies on an inhibitor of plasminogen activation in human serum. Release of the inhibitor during coagulation and thrombus formation. Thrombos. Diathes. haemorrh. (Stuttg.), 23, 553-561.

Bennett, N. B., Ogston, C. M., and Ogston, D. (1967). Studies on the blood fibrinolytic enzyme system following acute myocardial infarction. Clin. Sci., 32, 27-37.

Bergström, K., Blombäck, B., and Kleen, G. (1960). Studies on the plasma fibrinolytic activity in a case of liver cirrhosis. Acta med. scand., 168, 291-305.

Blombäck, B., Carlson, L. A., Franzen, S., and Zetterqvist, E. (1966). Turnover of ${ }^{131}$-I-labelled fibrinogen in man. Studies in normal subjects, in congenital coagulation factor deficiency states, in liver cirrhosis, in polycythaemia vera and in epidermolysis bullosa. Acta med. scand., 179, 557-574.

Das, P. C., and Cash, J. D. (1969). Fibrinolysis at rest and after exercise in heaptic cirrhosis. Brit. J. Haemat., 17, 431-443.

Fletcher, A. P., Biederman, O., Moore, D., Alkjaersig, N., and Sherry, S. (1964.) Abnormal plasminogen-plasmin system activity (fibrinolysis) in patients with hepatic cirrhosis: its cause and consequences. J. clin. Invest., 43, 681-695.

Goodpasture, E. W. (1914). Fibrinolysis in chronic hepatic insufficiency. Bull. Johns Hopk. Hosp., 25, 330-336.

Grossi, C. E., Moreno, A. H., and Rousselot, L. M. (1961). Studies on spontaneous fibrinolytic activity in patients with cirrhosis of the liver and its inhibition by epsilon amino caproic acid. Ann. Surg., 153, 383-393.

Grossi, C. E., Rousselot, L. M., and Panke, W. F. (1962). Coagulation defects in patients with cirrhosis of the liver undergoing portasystemic shunts. Amer. J. Surg., 104, 512-526.

Helle, I. (1968). Fibrinolysis and coagulation. Effect of calcium and of coagulation on the lysis of fibrin clots. Scand. J. Haemat., Suppl., 4.

Hilder, F. M., and Gunz, F. W. (1964). The effect of age on normal values of the Westergren sedimentation rate. J. clin. Path., 17, 292-293.

Johansson, S. A. (1964). Studies on blood coagulation factors in a case of liver cirrhosis. Remission of the haemorrhagic tendency or treatment with heparin. Acta med. scand., 175, 177-183.

Kwaan, H. C., Lo, R., and McFadzean, A. J. S. (1959). Antifibrinolytic activity in primary carcinoma of the liver. Clin. Sci., 18, 251-261.

Kwaan, H. C., McFadzean, A. J. S., and Cook, J. (1956). Plasma fibrinolytic activity in cirrhosis of the liver. Lancet, 1, 132-136.

Mattii, R., Ambrus, J. L., Sokal, J. E., and Mink, I. (1964). Production of members of the blood coagulation and fibrinolysin systems by the isolated perfused liver. Proc. Soc. exp. Biol. (N.Y.), 116, 69-72.

Merskey, C., Johnson, A. J., Kleiner, G. J., and Wohl, H. (1967) The defibrination syndrome: clinical features and laboratory diagnosis. Brit. J. Haemat., 13, 528-549.

Nilsson, I. M., and Olow, B. (1962). Fibrinolysis induced by streptokinase in man. Acta chir. scand., 123, 247-266.

O'Connell, R. A., Grossi, C. E., and Rousselot, L. M. (1964). Role of inhibitors of fibrinolysis in hepatic cirrhosis. Lancet, 2, 990-991.

Ogston, C. M., and Ogston, D. (1966). Plasma fibrinogen and plasminogen levels in health and in ischaemic heart disease. J. clin. Path., 19, 352-356.

Purcell, G., Jr.. and Phillips, L. L. (1963). Fibrinolytic activity in cirrhosis of the liver. Surg. Gynec. Obstet., 117, 139-144.

Rake, M. O., Flute, P. T., Pannell, G., and Williams, R. (1970). Intravascular coagulation in acute hepatic necrosis. Lancet, 1, 533-537.

Ratnoff, O. D. (1949). Studies on a proteolytic enzyme in human plasma. IV. The rate of lysis of plasma clots in normal and diseased individuals, with particular reference to hepatic disease. Bull. Johns Hopk. Hosp., 84, 29-42.

Ratnoff, O. D., and Menzie, C. (1951). A new method for the determination of fibrinogen in small samples of plasma. J. Lab. clin. Med., 37, 316-320.

Sherry, S., Lindemeyer, R. I., Fletcher, A. P., and Alkjaersig, N. (1959). Studies on enhanced fibrinolytic activity in man. $J$. clin. Invest., 38, 810-822.

Todd, A. S. (1958). Fibrinolysin autographs. Nature (Lond.), 181, 495-496.

Tytgat, G., Collen, D., De Vreker, R., and Verstraete, M. (1968) Investigations on the fibrinolytic system in liver cirrhosis. Acta Haemat., 40, 265-274.

Zetterqvist, E., and Franken, I. von (1963). Coagulation disturbances with manifest bleeding in extrahepatic portal hypertension and in liver cirrhosis. Preliminary results of hepatic treatment. Acta med. scand., 173, 753-760. 